\title{
ENERGY AND PROTEIN PRODUCTION \\ FROM PULP MILL WASTES
}

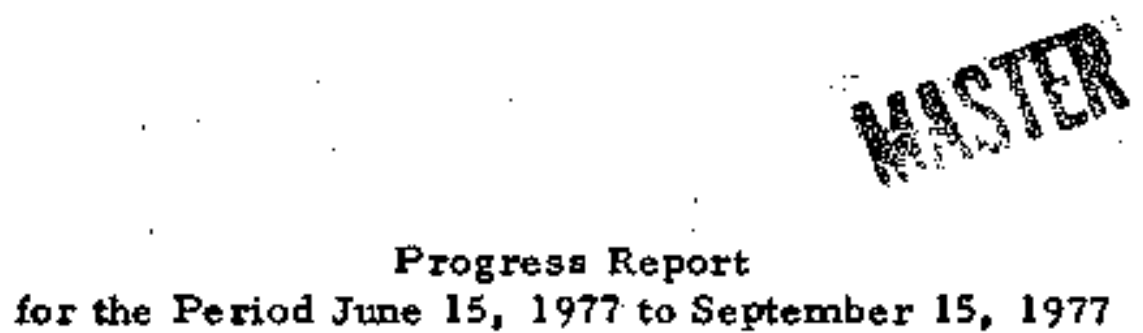

M. F. Jurgènşen and J. T. Patton

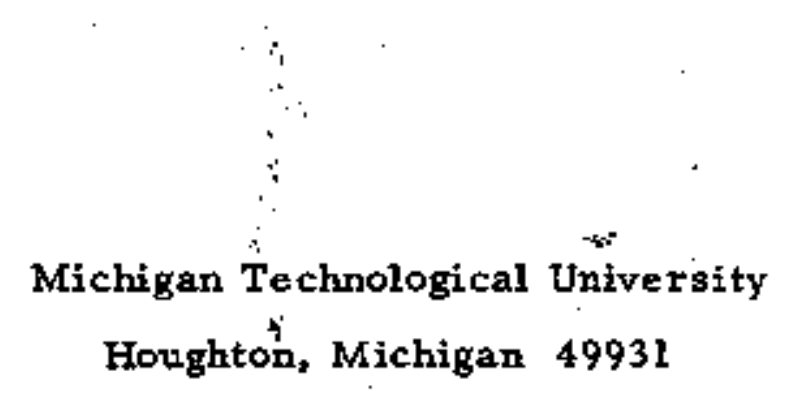

Sep̣tember 15, 1977

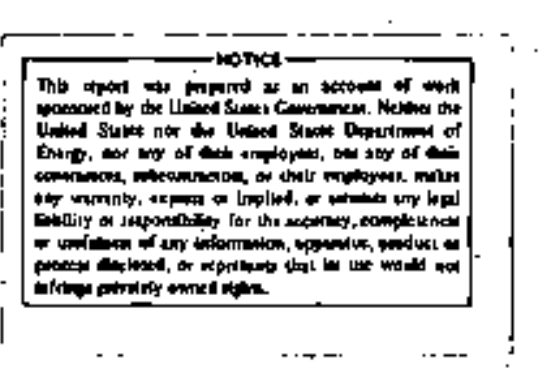

Prepared For

THE U. S. ENERGY RESEARCH AND DEVELOPMENT ADMINISTRATION

UNDER CONTRACT E(11-1)-2983 


\section{DISCLAIMER}

This report was prepared as an account of work sponsored by an agency of the United States Government. Neither the United States Government nor any agency Thereot, nor any of their employees, makes any warranty, express or implied, or assumes any legal liability or responsibility for the accuracy, completeness, or usefulness of any information, apparatus, product, or process disclosed, or represents that its use would not infringe privately owned rights. Reference herein to any specific commercial product, process, or service by trade name, trademark, manufacturer, or otherwise does not necessarily constitute or imply its endorsement, recommendation, or favoring by the United States Government or any agency thereof. The views and opinions of authors expressed herein do not necessarlly state or reflect those of the United States Government or any agency thereof. 


\section{DISCLAIMER}

Portions of this document may be illegible in electronic image products. Images are produced from the best available original document. 
NOTICE

This report was prepared as an account of work eponsored by the thited States Government. Neither the United States nor the United States Energy Research and Development Administration, nor any of their employees, makes any warranty, express or implied, or assumes any legal liability or responsibility for the accuracy, completeness, or usefulness of any information, apparatus, product or process disclosed or represents that its use would not infringe privately owned rights. 


\section{ABSTRACT}

Experinenta conducted during. this past quarter demonetrated the decided difference both in amount and composition of the gas produced from the fecmentation of ozonated versus unozonated yeast-plant SSL。 Gas from ozonated SSL averaged over $80 \%$ methane content whle unozonated effluent was mostly carbon dioxide, Gas production rates and retention time studies indfcated that the fermentetion was substrate-1imited. Prelininary teets usinB supplemental carbon sources have verifted this. The success of the ozonation process in producling. fermentable substrates was clearly shown by the appreciable yeast growth in the ozonated SSL, Of particular significance was the maximum yleld obtalned at the short ozonation time of 10 mintutes as compared to the 2-hour treatment. It is possible that shortening the ozonation time could also 1ncrease the anount of substrate available for methane production. Thy would be very important in transferring this process to a commercial basis and reducing the operating costs,

\section{BACKGROLND}

The eecond year bi "this project began after accomplishing the majority of the mlegtones projected in our inttial program plan. Methane-producing bacteria have been obtalned fron yarious sources and screened for their ability to grow on SSL. The effects of various ozonation treatnenta on the composition of SSL: have been established. Anaerobic continuous flow fermentors were developed and used to demonatrate the feasibility of producing methane from SSL. Durtug this past quarter emphasis was given to: (1) further work on optitsizing both the ozongtion and fermentation process and (2) evaluating sSL as a substrate for protein production by yeast. 


\section{STAFFING}

During this quarter the project was fully staffed. Two full-tine laboratory techniclans were employed during the summer to aid in the numetous chemical and biological tests which were routinely conducted. In addition, Dr. $\mathrm{Y}$. La1, a If gnin chen1st in the Forestry Department, spent one month working on the changes in the organic fraction of SSL after ozonation. At the beginning of September Dr. Patton left on a ntne-nonth leave of absence to New Mexico state Univergtty. He will continue working on the profect through pertodic tripe to Houghton and by correspondence. ThIs arrangenent has been coordfnated and approved by ERDA officials.

\section{RESULTS AND DISCUSSION}

\section{SSL Fermentation}

The anaerobic fernentors continued to be fin operation during this entire period. Obgervations in the early part of this quarter showed unexplatned Fluctuations in gas production during each 24-hour period. It was finally realized that these datly variatione due to uncontrollable changes in the amblent temperacure of the iaboratory. Consequently, a constant temperacure chamber was constructed which reduced temperatura fluctuations to less than $\pm 1^{\circ} \mathrm{C}$ during the measuring period.

All the ferwentors were fed 75\% yeart-plant SSL which had been ozonated for 3 hours. The gradual decline in gag production noted in the lagt reporting pertod halted, and gas production atabilized at approxtoately $10 \mathrm{mls} / \mathrm{hr}$. Wo explanation is evident to account for this lowering of gas output. The conposition of the gas from the reactorg still showed the high proportion of methane to çarbon dloxfde noted In earlier studies (Table 1). Continued decreases is OCD and BOD levels were also observed. 
TABLE I. Properties of yeast plant SSL during continuous flow fermentation over a one-month period.

\begin{tabular}{|c|c|c|c|c|c|c|c|c|c|}
\hline $\begin{array}{l}\text { Average } \\
\text { Tinte at } \\
\text { Steady } \\
\text { State } \\
\text { (days) }\end{array}$ & $\begin{array}{l}\text { Retention } \\
\text { Time } \\
\text { (days) }\end{array}$ & $\begin{array}{l}\text { COD } \\
(8)\end{array}$ & $\begin{array}{l}\text { BOD } \\
\left(\frac{8}{4}\right)\end{array}$ & $\begin{array}{c}\text { SUIFUR } \\
(\$)\end{array}$ & $\begin{array}{l}\text { Production } \\
\text { (mls/hr) }\end{array}$ & $\begin{array}{l}\mathrm{Com}_{2} \\
\mathrm{CO}_{2} \\
(\%)\end{array}$ & $\begin{array}{r}\mathrm{CH}_{4} \\
(b)\end{array}$ & $\begin{array}{l}\text { Methane } \\
\text { Protucers } \\
\left(x 10^{7}\right)\end{array}$ & $\begin{array}{c}\text { Desulfovibrio } \\
\cdot\left(\times 10^{7}\right)\end{array}$ \\
\hline 8 & 5.1 & -7.2 & -33.7 & - & 12 & 19.4 & 80.6 & 50 & 60 \\
\hline 6 & 3.4 & -17.0 & -37.5 & -9.9 & 10 & 21.8 & 78.2 & 203 & 186 \\
\hline hozonat & SSL ** & & & & & & & & \\
\hline
\end{tabular}

* Yeast plant effluent ozonated for 3 hours at pH 3. Values are an average from two fermentors.

** Untreated yeast plant effluent. Values from one fernentor. 
In order to establish the level of gas production which can be supported in untreated yeast-plant effluent, one reactor was fed a medium of $75 \%$ unozonated SSL. The regults from this test showed the general lack of metabolizable substrate In unozonated effluent. Gas production was only a quarter of that obtained from ozonated SSE reactore and was compoed ainost entirely of carbon dioxide (Table 1).

Analysts of reactor performance during this period indicated that the fermentation process appesred to be substrate limited. Consequently, various nutrient Bupplenents have been added to the SSL to determine what the limiting substrate or substrates may be. To date, vitamins, therals and several organle acids and alcohols have been tested, several of which gave decided stinualtions of methane production. These gtudies will be continued in the following quarter.

\section{Mieroblal Analyeis}

The populations of the anserobic methane-producting and the sulfur-reducing bacterta were wonitored during each reactor op ration. The gradual decrease in methane bacteria noted earlier appeared to balt and populations of both methaneproducers and pegulfovibrio increased drasatically. In all of the reactors the populatlons of both methane-producers and aulfur-reducers were approximately * equal, averaging nearly $5 \times 10^{9}$ organtams/ml at steady btate conditions. Deterninations were also tun on non-methane producing anaerobes and facultative anaerobes using the standard plate count technique. Prelininary results of these tests Indicated equal populations of each approxtmating $10^{6}$ organisms/ 1.

Our standard Hungate procedure used to monttor populations of nethaneproducing bacteria and Desulfovibrto was modified during this period. Based on the research results from the University of Illinols, the purging gas used in the preparation of the annerobic fingate tubeg was changed fron pure carbon 
d1oxide to one containing a nixture of $50 \%$ carbon dioxide and $50 \%$ hydrogen. Preliminary tests have indicated higher population counts by a factor of 10 usIng this technique. This method is now belgg routinely used in our laboratory.

\section{Protein Production}

The project initiated on proteln production from yeast-plant treated SSL at the end of the last quarter was continued and expanded during the sumper. Cultures of Torula yeast were inoculated Into flasks of either unozonated or ozonated SSL. Vartous SSL ozonation times were used, which ranged from 10 minuces to 2 hours. In addition, nitrogen, phosphorous and potasalum were added as supplewents. The cultures were grown on a rotary shaker for up to elght days. Perlodically duplicate flasks were centrifuged, dtied and the residue weight deternined. Yeast production was expressed as the amount of dry wetght produced in each flask. The results of the tests are ohow in Figure 1.

Some yeast development occurred in all the treatments. Yeast grosth on the unozonated SSL was fairly low reaching a stable population after 3 days. Unexpected was the high yield found in the SSL ozonated for 10 minutes and the poor yeast development in the 2-hour ozonated SSL. The 10-minute treatment ahowed a drematis production peak at 2 days and a very rapid decrease on the third day. This decrease Is likely attributable to autolysis of the yeast cells. After 7 days there was very IIttle difference In yesst yield among the various SSL treated media. It appears that the lower yeagt yields after. longer SSL ozonation treatnents are related to a reduction in carbon available for yeast growth.

The growth of Torula yeast on ozonated yeast-plant SSL is apprectable, with yields approaching $10 \%$ of those obtained from yeast plants using raw SSL. Work is continuing on this process to more precisely determine the optimum ozonation time and growth conditions for maxinum yeast production. 
Bxperineats in this quarter demonstrated the dectded difference both in atrount and composition of the gas produced from the fermentation of azonated vs unozonated yeast-plant SSL. Gas production rates and retention tine studies Indicated that the fermentation was carbon-1imited. Frelininary tests using supplemental carbon sources have verified this. The success of the ozonation process in producing fermentable subatrates was clearly shown by the apprectable yeast growth in the ozonated SSL. Of particular signtficance wss the naximum yield obtained at the short ozonation time of 10 minutes as compared to the 2hour traatment. It is posalble that reducing the ozonation tine could also Increase the amount of substrate available for methane production. This would be very important in transferring this process to a cotwercial basts and reducing the operating costs.

\section{PLANS FOR THE FUTURE}

During the coming quarter the characterization of optinum SSL ozonation time fox protein production will be continued. In addition, the effect of SSL ozppation time on methane production will also be examined. More detatled experiments sill be conducted to quantify the types and amouncs of netabolizable substrates wh1ch are present in yeast-plant SSL after the various ozonation treatoents. 